\title{
Pemberdayaan Majelis Gereja Untuk Pencegahan HIV dan AIDS Di Amanatun Utara Nusa Tenggara Timur
}

\author{
Imelda Februati Ester Manurung \\ Fakultas Kesehatan Masyarakat, Universitas Nusa Cendana \\ imelda.manurung@staf.undana.ac.id
}

\begin{abstract}
Abstrak
Kasus HIV dan AIDS saat ini tidak saja ditemukan di populasi kunci, tetapi juga sudah di populasi umum seperti ibu rumah tangga di pedesaan. Tingginya migrasi penduduk desa untuk mencari kerja di luar daerah merupakan salah satu faktor risiko terjadi penularan HIV. Masyarakat desa pada umumnya masih mempercayai tokoh rohani seperti majelis gereja dalam menyampaikan pesan kesehatan. Untuk itu pengabdian ini bertujuan untuk memberdayakan majelis gereja untuk memberikan dukungan pencegahan HIV di masyarakat. Metode pelaksanaan yaitu dengan pelatihan disertai pre dan pos tes serta praktek keterampilan dukungan pencegahan HIV. Pada akhirnya majelis diminta untuk membuat rencana kerja selama 1 bulan setelah pelatihan kemudian dilakukan monitoring dan evaluasi. Hasil dari pengabdian ini adalah terjadi peningkatan pengetahuan tentang HIV dan AIDS, penularan, pencegahan dan pengobatannya. Selain itu keterampilan dukungan pencegahan HIV juga meningkat. Majelis juga melakukan seluruh rencana kerja yaitu memberikan dukungan pencegahan HIV minimal pada tiga orang yang berpotensi tertular HIV seperti bekas TKI atau pekerja di luar daerah. Kesimpulan dari pengabdian ini yaitu perlu memberdayakan seluruh komponen desa untuk melakukan upaya pencegahan HIV dan AIDS di seluruh lapisan masyarakat desa dengan tingkat migrasi penduduk cukup tinggi.
\end{abstract}

Kata kunci: pemberdayaan, majelis, HIV dan AIDS

\begin{abstract}
HIV and AIDS cases are currently not only found in key populations but also in the general population, such as rural housewives. The high migration of villagers to look for work outside their current areas is one of the risk factors for HIV transmission. The village community in general still believes in spiritual figures, such as church assemblies, in delivering health messages. For this purpose, the service aims to empower church assemblies to provide HIV prevention support in the community. The method of implementation is by training with pre and test posts as well as practice with HIV prevention support skills. In the end, the assembly was asked to make a work plan for one month after the training and then carried out monitoring and evaluation. The result of this service is an increased in knowledge about HIV and AIDS, transmission, prevention, and treatment. In addition, HIV prevention support skills have also increased. The assembly also carried out all work plans, including providing minimum HIV prevention support to three people who have the potential to contract HIV such as former migrant workers or workers outside the area. The conclusion of this service is the need to empower all village components to make efforts to prevent HIV and AIDS in all levels of the village community with high levels of population migration.
\end{abstract}

Keywords: empowerment, assembly, HIV and AIDS 


\section{PENDAHULUAN}

Laju epidemi HIV dan AIDS yang sangat cepat sudah menjadi masalah global. Jumlah kasus HIV dan AIDS di Indonesia pada tahun 2016 mencapai 319.103 kasus meningkat dibandingkan tahun 2015 yang mencapai 268.185 kasus $^{1}$ (KPAN, 2017). Seluruh provinsi di Indonesia sudah ditemukan kasus HIV dan AIDS yang setiap tahunnya menunjukkan peningkatan. Kasus kumulatif HIV dan AIDS di Provinsi Nusa Tenggara Timur (NTT) juga meningkat dari 4.581 kasus pada tahun 2016 menjadi5.771 kasus pada $2012^{2}$. Bahkan kasus paling tinggi ditemukan pada kelompok yang berprofesi sebagai ibu rumah tangga.

Banyak faktor yang memicu penularan penyakit ini seperti perilaku berisiko, rendahnya pengetahuan dan kesadaran untuk tes HIV. Persepsi negatif atau stigma terhadap penyakit HIV dan AIDS membuat masyarakat merasa malu untuk membicarakannya. HIV dan AIDS dikaitkan dengan penyakit hukuman, ODHA harus dikucilkan, malu untuk tes HIV adalah contoh perilaku yang muncul akibat dari pengetahuan masyarakat tentang HIV dan AIDS masih rendah. Berbagai upaya sudah banyak dilakukan untuk mengendalikan penyebaran HIV dan AIDS. Pendidikan kesehatan tentang HIV dan AIDS lebih sering dilakukan di daerah perkotaan. Padahal banyak masyarakat desa yang menjadi buruh di perkotaan. Mereka berangkat ke kota meninggalkan keluarga tanpa memiliki informasi yang baik tentang kesehatan termasuk penularan HIV dan AIDS. Sehingga masyarakat di desa menjadi sasaran yang potensial untuk dilakukan pendidikan kesehatan HIV dan AIDS.

Pendidikan kesehatan HIV dan AIDS bertujuan untuk meningkatkan pengetahuan, sikap dan perilaku seseorang untuk dapat melakukan berbagai upaya pencegahan penyakit tersebut. Data dari Gereja Masehi Injili Timor (GMIT) Klasis Amanatun Utara tahun 2017 menunjukkan kecendrungan migrasi warga jemaat (725 orang) akibat berbagai faktor diperparah karena minimnya informasi yang mereka miliki mengenai risiko migrasi. Kelompok migrasi tertinggi adalah pemuda dan anakanak di Klasis Amanatun Utara sebanyak 56,1\% dengan tingkat pendidikan tamat Sekolah Dasar ke bawah sebanyak 31,7\%. Menurut data tersebut, modus migrasi adalah karena diajak oleh orang lain (61,79\%), dan mau memperbaiki ekonomi keluarga tapi tanpa pekerjaan di Amanatun Utara $(54,21 \%)^{3}$. Data ini menunjukkan dua di antara faktor pendorong lain untuk orang bermigrasi, yaitu kemiskinan dan tingkat pendidikan yang rendah. Kemiskinan juga terjadi akibat banyak faktor seperti sistim ekonomi, infrastruktur, kebijakan yang kurang adil, dan kemarau panjang berdampak besar di NTT. Kondisi ini memicu migrasi warga jemaat sehingga terjebak dalam mafia perdagangan orang, baik dari proses direkrut sampai tujuan dan cara dipekerjakan. Banyak warga jemaat kembali ke NTT dengan kondisi kesahatan buruk, termasuk tertular HIV-AIDS ataupun telah meninggal (pada April 2018 telah 25 jenasah dikembalikan ke NTT).

Melihat fenomena di atas maka masyarakat Amanatun Utara menjadi kelompok berisiko tinggi penularan HIV. Migrasi ke luar daerah dengan meninggalkan keluarga serta paparan kehidupan sosial yang berbeda antara kota dan desa menjadi potensi risiko penularan HIV. Tokoh agama di masyarakat pedesaan terbukti mampu untuk memberikan pengaruh positif dalam kehidupan. Untuk itu penting melakukan

\footnotetext{
${ }^{1}$ Komisi Penanggulangan AIDS Nasional, (2017) Laporan Kementrian Kesehatan Triwulan IV, 2016 http://www.aidsindonesia.or.id/list/7/Laporan-Menkes

${ }^{2}$ Komisi Penanggulangan AIDS Provinsi NTT,(2018) Laporan Tahunan KPA Provinsi NTT. Kupang

${ }^{3}$ BPS Provinsi NTT, 2018. Statistik Daerah Provinsi Nusa Tenggara Timur, 2018. Kupang
} 
pengabdian berupa pemberdayaan Majelis Gereja GMIT Klasis Amanatun Utara dalam memberikan dukungan pencegahan HIV di masyarakat.

\section{METODE PELAKSANAAN}

Kegiatan pengabdian dilaksanakan pada bulan Juni - Agustus 2018 di Klasis Amanatun Utara Kabupaten Timor Tengah Selatan Provinsi Nusa Tenggara Timur. Sasaran ditujukan pada 30 orang Majelis Gereja GMIT. Tahap pelaksanaan kegiatan dimulai dengan identifikasi peserta, persiapan pelatihan, pelatihan (materi, praktek dan skrining, penyusunan rencana aksi), implementasi rencana aksi monitoring dan evaluasi. Untuk lebih jelasnya dapat dilihat pada gambar l di bawah ini.

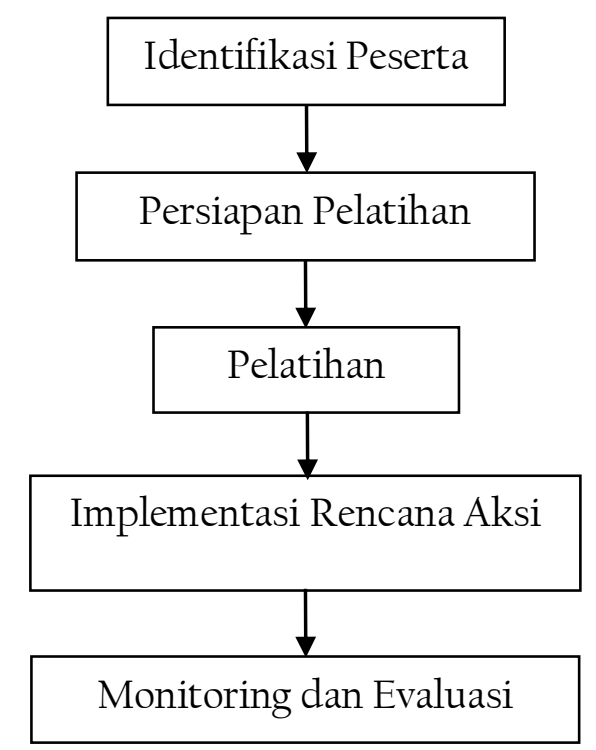

Gambar 1. Tahap Pelaksanaan Kegiatan

Identifikasi peserta berdasarkan komitmen untuk mengikuti seluruh rangkaian kegiatan sehingga diperoleh 30 orang. Persiapan pelatihan yaitu dengan mempelajari kembali Modul Pemberdayaan Masyarakat untuk Penanggulangan HIV dan AIDS ${ }^{4}$. Selain peserta, para tokoh agama dan masyarakat juga diundang untuk kegiatan pelatihan. Pelatihan dilaksanakan selama 2 hari dengan waktu 10 jam dengan melakukan pre-post test untuk melihat perubahan pengetahuan dan keterampilan. Kegiatan pelatihan berisi tentang materi penularan, pencegahan dan pengobatan HIV dan AIDS. Peserta juga diminta mempraktekkan beberapa contoh kasus untuk meningkatkan keterampilan pencegahan HIV.

Pada akhir pelatihan peserta diminta untuk tes HIV dan membuat rencana aksi sebagai program kegiatan pada 1 bulan berikutnya setelah dilakukan pelatihan. Rencana aksi yaitu berupa dukungan pencegahan HIV kepada masyarakat diprioritaskan pada keluarga yang terpisah jauh kerena menjadi TKI atau bekerja di kota, juga pada orang yang baru datang dari luar desa dan yang hendak bekerja ke kota. Implementasi rencana aksi dilakukan selama 1 bulan yang disertai dengan monitoring dan evaluasi.

\footnotetext{
${ }^{4}$ Manurung, 2017. Modul pelatihan pemberdayaan masyarakat untuk penanggulangan HIV dan AIDS.
} Kupang 
Pada tahap monitoring dan evaluasi dilakukan untuk melihat sejauh mana rencana aksi pada saat pelatihan dilakukan. Kegiatan monitoring dan evaluasi dilakukan selama 2 kali.

\section{HASIL DAN PEMBAHASAN}

Pelatihan bagi majelis gereja bertujuan untuk meningkatkan pengetahuan dan keterampilan dukungan pencegahan HIV pada masyarakat. Dari hasil pelatihan terdapat peningkatan yang signifikan pada pengetahuan dan keterampilan memberikan dukungan pencegahan HIV pada masyarakat. Informasinya dapat dilihat pada tabel 1 berikut:

Tabel 1. Pengetahuan dan keterampilan dukungan pencegahan HIV dan AIDS

\begin{tabular}{|c|c|c|c|c|c|c|}
\hline \multirow[t]{3}{*}{ Penilaian Variabel } & \multicolumn{6}{|c|}{ \% Tingkat Penguasaan Peserta } \\
\hline & \multicolumn{3}{|c|}{ Pre Test } & \multicolumn{3}{|c|}{ Pos Test } \\
\hline & Baik & Cukup & $\begin{array}{l}\text { Kuran } \\
\text { g }\end{array}$ & Baik & Cukup & Kurang \\
\hline \multicolumn{7}{|l|}{ 1. Pengetahuan: } \\
\hline a. Defenisi HIV dan AIDS & 20 & 40 & 40 & 80 & 10 & 10 \\
\hline b. Penularan & 10 & 40 & 50 & 75 & 10 & 15 \\
\hline c. Pencegahan & 25 & 30 & 45 & 85 & 5 & 10 \\
\hline d. Pengobatan & 15 & 35 & 50 & 75 & 20 & 5 \\
\hline \multicolumn{7}{|c|}{ 2. Keterampilan Dukungan Sosial } \\
\hline a. Informasi & 15 & 25 & 60 & 75 & 20 & 5 \\
\hline b. Appraisal & 10 & 20 & 70 & 75 & 15 & 10 \\
\hline c. Instrumental & 10 & 15 & 75 & 85 & 10 & 5 \\
\hline d. Emosional & 25 & 35 & 40 & 90 & 5 & 5 \\
\hline
\end{tabular}

Pada tabel di atas variabel nilai untuk pengetahuan dan keterampilan sebelum dilakukan pelatihan paling banyak memiliki nilai kurang. Namun setelah dilakukan pelatihan sebagian besar dalam kategori baik. Pengetahuan tentang penularan HIV merupakan topik yang paling hangat di bicarakan. Karena hampir seluruh peserta memiliki persepsi yang salah dimana HIV dapat menular melalui jabat tangan, tinggal serumah, gigitan nyamuk, pakaian dan lainnya. Setelah mendapat penjelasan peserta pun menerima informasi yang benar tersebut. Peserta juga mempraktekkan bagaimana memberikan dukungan informasi, appraisal, instrumental dan emosional pada orang yang berisiko.

Seluruh peserta aktif mengikuti pelatihan baik dalam bertanya, menjawab dab berdiskusi pada setiap pertanyaan Selain itu seluruh peserta juga hadir dari awal hingga akhir pertemuan.

Pengetahuan dan keterampilan dukungan menjadi modal bagi majelis untuk melakukan rencana aksi atau komitmen untuk memberikan dukungan pencegahan HIV di masyarakat. Dari hasil monitoring dan evaluasi seluruh peserta melakukan rencana aksinya yaitu memberikan dukungan pencegahan HIV dan AIDS minimal pada 3 orang tetangga, sahabat atau keluarga. Bahkan ada peserta yang memberikan dukungan kepada 15 orang. Dukungan yang diberikan berupa informasi penularan, pencegahan dan pengobatan HIV dan AIDS.

Pengetahuan dan keterampilan merupakan indikator dari keberdayaan. Peningkatan terhadap nilai pengetahuan dan keterampilan akan meningkatkan keberdayaan majelis. Model pemberdayaan dipengaruhi oleh variabel pengetahuan, 
keterampilan dan dukungan masyarakat ${ }^{5}$. Pengetahuan dan keterampilan merupakan faktor bagi seseorang untuk dapat diberdayakan ${ }^{6}$. Rendahnya pengetahuan dan keterampilan mengakibatkan sulitnya individu diberdayakan untuk menolong dirinya sendiri bahkan untuk menolong orang lain ${ }^{7}$. Seseorang mau dan mampu melakukan aktivitas dengan benar karena memiliki pengetahuan dan keterampilan yang baik. Demikian juga hasil dari pengabdian ini menunjukkan bahwa perbaikan pengetahuan dan keterampilan pada majelis gereja telah mampu mendorong mereka untuk memberikan dukungan pencegahan HIV di masyarakat. Majelis gereja merupakan tokoh yang sangat dihormati masyarakat dalam konteks pelayanan rohani sehingga pesan yang disampaikan mereka akan lebih diingat.

\section{KESIMPULAN DAN SARAN}

Kegiatan pengabdian ini telah mampu memberdayakan majelis gereja untuk memberikan dukungan pencegahan HIV pada masyarakat berisiko tinggi seperti keluarga yang menjadi TKI atau yang akan dan sudah bekerja di luar daerah. Hal ini dapat dilihat bahwa seluruh majelis melakukan komitmen rencana aksi dalam pelatihan yaitu memberikan dukungan pencegahan HIV. Kegiatan mereka juga diterima baik oleh masyarakat. Pemberdayaan majelis dapat dilakukan dengan didahului pelatihan pencegahan HIV. Hal ini dikarenakan masih rendahnya pengetahuan dan keterampilan pencegahan HIV di masyarakat.

Perlu dilakukan upaya-upaya yang melibatkan seluruh komponen desa untuk edukasi pencegahan HIV. Hal ini dikarenakan tingginya migrasi masyarakat di desa yang meninggalkan keluarga. Komunikasi, edukasi dan informasi HIV dan AIDS yang menggunakan pendekatan lokal akan diterima dengan baik oleh masyarakat.

\section{UCAPAN TERIMA KASIH}

1. Sinode GMIT, para majelis dan pendeta Provinsi Nusa Tenggara Timur.

2. Dekan FKM Undana Kupang

3. Seluruh masyarakat/jemaat Klasis Amanatun Utara.

\section{DAFTAR PUSTAKA}

BPS Provinsi NTT, 2018. Statistik Daerah Provinsi Nusa Tenggara Timur, 2018. Kupang Brodsky, E.A., Cattaneo, L.B. (2013) A Trans Conceptual Model of Empowerment and Resilience: Divergence, Convergence and Interactions in Kindred Community Concepts. American Journal of Community Psychology, Vol. 52, No. 3-4, pp. 333-346.

Brugge, D., Edgar, T., George, K., Heung, J., Laws, M. (2009) Beyond Literacy and Numeracy in Patient Provider Communication: Focus Group Suggest Roles for Empowerment, Provider Attitude and Language. BMC Public Health, Vol. 9, No. 354, pp.1-11.

Komisi Penanggulangan AIDS Nasional, (2017) Laporan Kementrian Kesehatan Triwulan IV, 2016 http://www.aidsindonesia.or.id/list/7/Laporan-Menkes

\footnotetext{
${ }^{5}$ Brodsky, E.A., Cattaneo, L.B. (2013) A Trans Conceptual Model of Empowerment and Resilience: Divergence, Convergence and Interactions in Kindred Community Concepts. American Journal of Community Psychology, Vol. 52

${ }^{6}$ Phan, L. (2016) Measuring Women's Empowerment at Household Level Using DHS Data of Four Southeast Asian Countries. Social Indicators Research, Vol. 126, No. 1, pp. 359-378.

${ }^{7}$ Brugge, D., Edgar, T., George, K., Heung, J., Laws, M. (2009) Beyond Literacy and Numeracy in Patient Provider Communication: Focus Group Suggest Roles for Empowerment, Provider Attitude and Language. BMC Public Health, Vol. 9, No. 354, pp.l-11
} 
Komisi Penanggulangan AIDS Provinsi NTT,(2018) Laporan Tahunan KPA Provinsi NTT. Kupang

Manurung, 2017. Modul pelatihan pemberdayaan masyarakat untuk penanggulangan HIV dan AIDS. Kupang

Phan, L. (2016) Measuring Women's Empowerment at Household Level Using DHS Data of Four Southeast Asian Countries. Social Indicators Research, Vol. 126, No. 1, pp. 359-378.

Sinode GMIT, 2017. Laporan Pelayanan Sinode GMIT, Kupang.

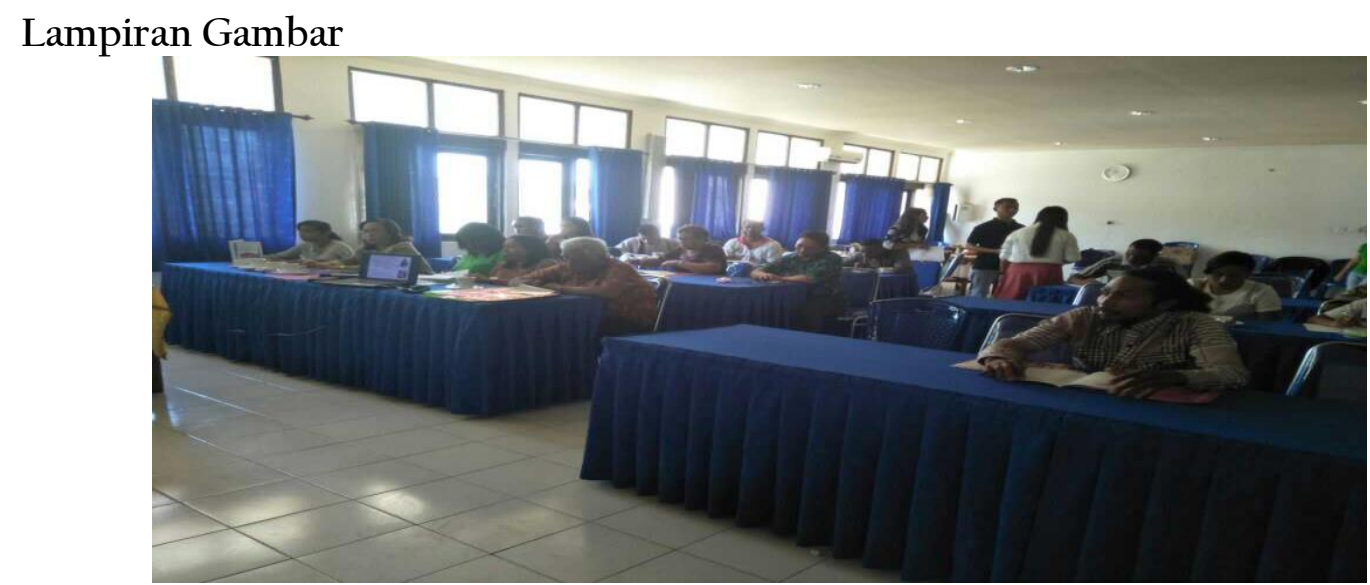

Gambar l. Kegiatan Pelatihan pemberdayaan Majelis Gereja Untuk Pencegahan HIV dan AIDS

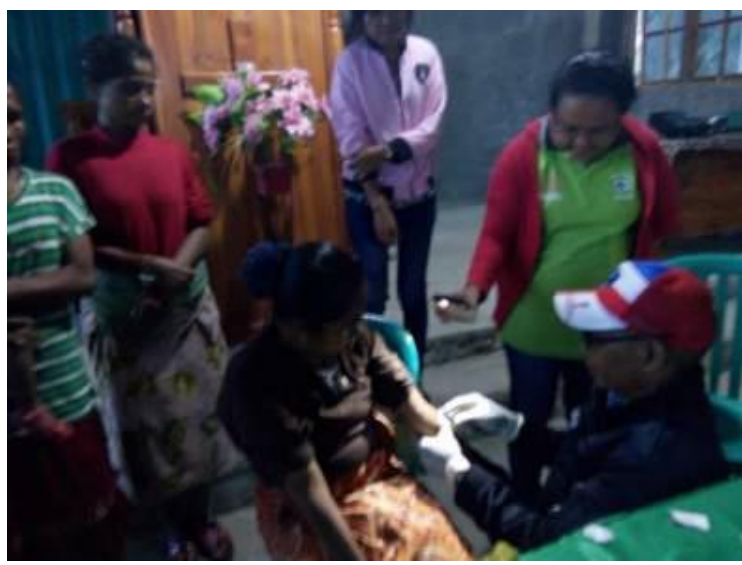

Gambar 2. Kegiatan skrining pada masyarkat yang difasilitasi oleh kelompok Majelis Gereja

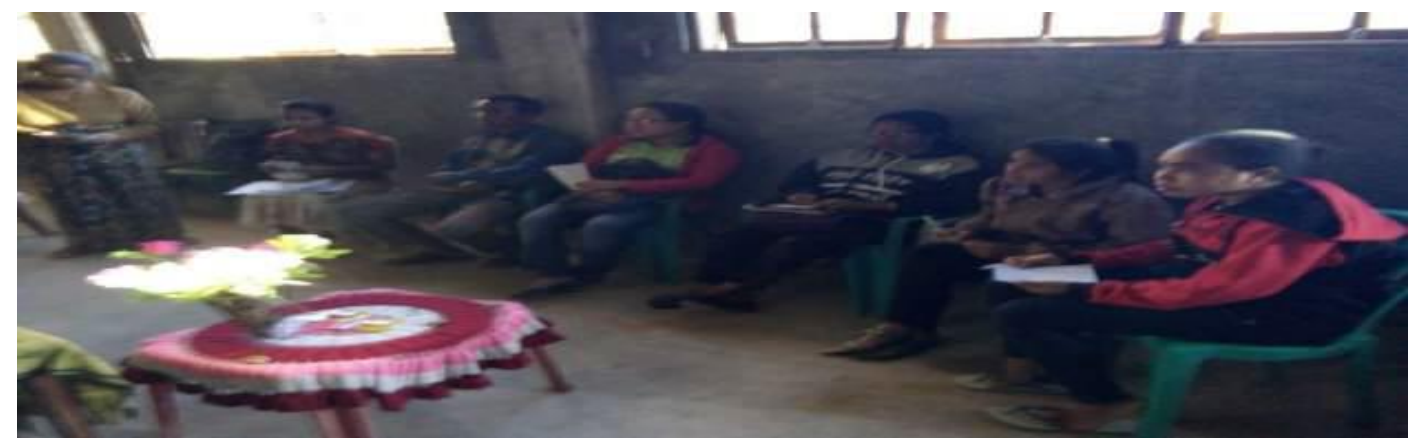

Gambar 3. Kegiatan monitoring dan evaluasi rencana aksi majelis dalam memberikan dukungan pada orang berisiko HIV 